\title{
Political Reforms and Women's Economic Empowerment in Khyber Pakhtunkhwa
}

\author{
(Pakistan) \\ * Muhammad Bilal, Lecturer (Corresponding Author) \\ ** Dr. Akhlaq Ahmad, Assistant Professor \\ *** Dr. Qaisar Khalid Mahmood, Assistant Professor
}

\begin{abstract}
Women empowerment is an important discourse among the academic circles, especially in the feminist debates. The economic independence of women remains under discussion too because it fuels their overall empowerment. This paper mainly concentrates to examine the impact of political changes on female's economic empowerment in Khyber Pakhtunkhwa (KP), Pakistan. Moreover, this also focuses to know women's knowledge about the political reforms brought for their empowerment. Liberal feminist camp supports the theoretical insights of this study. Empiricist epistemology guides the methodological application of the study. A sample of 400 women political representatives was taken through proportionate random sampling. Data were collected through interview schedule. Content analysis and independent sample t-test techniques helped in data analysis. Findings reveal some minor effects of the political reforms (i.e. increase of women quota in jobs and protection to women from workplace harassment); however, women's economic independence in the study area still needs serious attention from different public and private stakeholders.
\end{abstract}

Keywords: Women Political Representatives, Political Changes, Economic Empowerment of

\section{Introduction}

Females, Anti-harassment Bill, Female's Paid Work

Women empowerment has been a subject of concern for feminist debates. The modern feminist discourse considers it as rising, difficult and multi-dimensional idea (Hassan, 2009). The multidimensionality of women empowerment comprises of legal, political, social, familial, educational, and economic etc. however, women's economic empowerment is of utmost significance because it fuels all other aspects of their empowerment. Women across the countries constitute almost half of the population but unfortunately, they are economically dependent. Their economic dependence on men has seriously affected all their other (social, legal, political, familial, etc.) areas of life. In Pakistan, women too constitute almost half of the population but most of them are not economically independent (Agbalajobi, 2010).

In Pakistan, women empowerment has been on priority agendas for various governments. They claim for bringing reforms to improve women's status legally, politically, and socioeconomically (Yazdani, 2003). Different governments tried to bring reforms to improve women status. These reforms are known as women quota in the parliament, women quota at KP's local government, anti-women harassment bill, and women quota in the government services especially in the central superior services exam and in provincial management services exam at KP (Zia, 2018). This study tried to examine the actual impact of the mentioned reforms on the economic independence of females in Khyber Pakhtunkhwa, Pakistan.

\section{Literature and Theoretical Underpinnings}

Pakistan is labeled as a patriarchal society (Caldwell, 1982) where men are the main earning sources for their families and this phenomenon has been superseded women and revealed men's domination

\footnotetext{
* Department of Sociology, Abdul Wali Khan University Mardan (Main Campus), KP Pakistan

Email: Bilal@awkum.edu.pk

** Department of Sociology, International Islamic University Islamabad.

*** Department of Sociology, International Islamic University Islamabad.
} 
over women (Tabassum et al., 2013). The dominant role of men over women is socially and culturally structured in Pakistan (Naz \& Ahmad, 2012) and it clear that from the studies that weak economic status of women is the major cause of their subordination (Ullah, 2018). Women's empowerment is mainly based on their economic position in which their paid labor is an important element. Allowing women for paid labor is the sole responsibility of their families in which cultural and social forces over family are the key hindrances(Tabassum et al., 2013). (Tabassum et al, 2013). Empowering women is the responsibility of both the genders (men and women) as CIDA in 2010 declares that; "Empowerment is about people - both women and men-taking control over their lives: setting their agendas, gaining skills, building self-confidence, solving problems, and developing selfreliance, it is not only a collective, social and political process, but an individual one as well -and it is not only a process but an outcome".

The instrumental definition of women's empowerment understands that it is a capital for family, society, and the nation at large (Hassan, 2009). In modern sociological debate capital is defined as "the accumulated goods devoted to the production of other goods". Nevertheless, dividing the capital into four types (economic, social, symbolic, and cultural) the central role is given to economic capital (Sadruddin, 2013). Taking women empowerment in the context of capital to the country/nation, women's economic empowerment is the significant contributing capital to the development of a nation. Considering women as one of the important contributing capitals to national development, the government of Pakistan attempted to empower women in the social, legal, political, including economic domains of life. This attempt is revealed in the shape of the following political reforms, brought for women's empowerment.

Anti-women's Harassment Legislation was made in connection to female's social protection in the public domain; the government of Pakistan has made a law with the title of anti-women's harassment bill. This reform is brought for women protection in the public domain(s) to give them a secure feeling during their paid labor at the market (Sadruddin, 2013). This reform was fetched to socially protect women during performing their job(s) easily and having an independent economic life. If women become economically independent then their overall life's capital is a sound contributing factor to the national economy.

Similarly, another reform concerning female's jobs was brought with the name of women quota in central superior services (CSS) examination at the national level. Considering women paid services and their exposure to the public sphere, the government of Pakistan has increased the number of seats for women up to $10 \%$ in each group of CSS examination. This reform was brought in 2006 and was implemented respectively (BILAL et al., 2016). This reform was brought mainly to empower women economically and take their paid services in the market. However, this reform is not justified for all of the women to be empowered because only a few percent of the women could become beneficiary of the said reform and has no effect over the empowerment of overall women population of the country (Kabir, 2013).

Likewise, women were granted quota in the provincial management services (PMS) at the KP province of Pakistan. Women seats in the said services were increased by up to $10 \%$. The understanding behind this reform was to give an extra space to qualified women at the KP province to be practically involved in the management/administration of the different districts and civil secretariat level as well (Kabir, 2013). This reform was also not fruitful for the general women's economic empowerment because only a nominal number of women at KP province achieves higher education and could come to the position to attempt PMS examination.

The discourse of women empowerment through political reforms is very common in the academic endeavors (Moghadam, 2010). However, the current literature focuses specifically on the economic empowerment of females through political reforms. Economic empowerment, for example, can be quantified through women's paid work; their contribution in family, female's access to family resources, and their hold on family income and other resources (Verge and De la, 2014; Duflo, 2012; Abdullah and Fofana, 2010; Abu-Lughod, 2009). Women's economic empowerment can be ensured through many approaches; nevertheless, one effective method for it is the political changes that are to be brought through policy level (Goetz and Gupta, 1996). Women empowerment through political reforms is widely debated among feminist circles but liberal feminist debates are more central to this discourse (Marilley, 1996). 
The key theoretical idea for this study comes from liberal/mainstream feminism. As the most moderate branch of feminism, liberal/mainstream feminism argues that all people are created equal and should not be denied equality of opportunity because of gender (Lindsey, 2015). It further believes that empowering women does not need the whole society to be restructured, however, gradually through bringing societal reforms women should be brought to the mainstream where than can have better economic opportunities that they can avail and make an equal social position to men in the society. Liberal feminism draws its main idea from John Stuart Mill's philosophy of the subjection of women where he believes that the idea of women nature is a social construction and it is unnatural because this construction took place through forced oppression (Mill, 1869). The logic behind the selection of liberal feminism as a theoretical framework of the study is that it argues for women empowerment through bringing societal reforms slowly and gradually. The main strand of liberal feminism is in direct connection with the study key objective because it examines the effect of the political reforms on the actual economic empowerment of the females' political representatives. From liberal feminism, this study mainly uses the idea of bringing reforms for women empowerment and not restructuring the society as a whole.

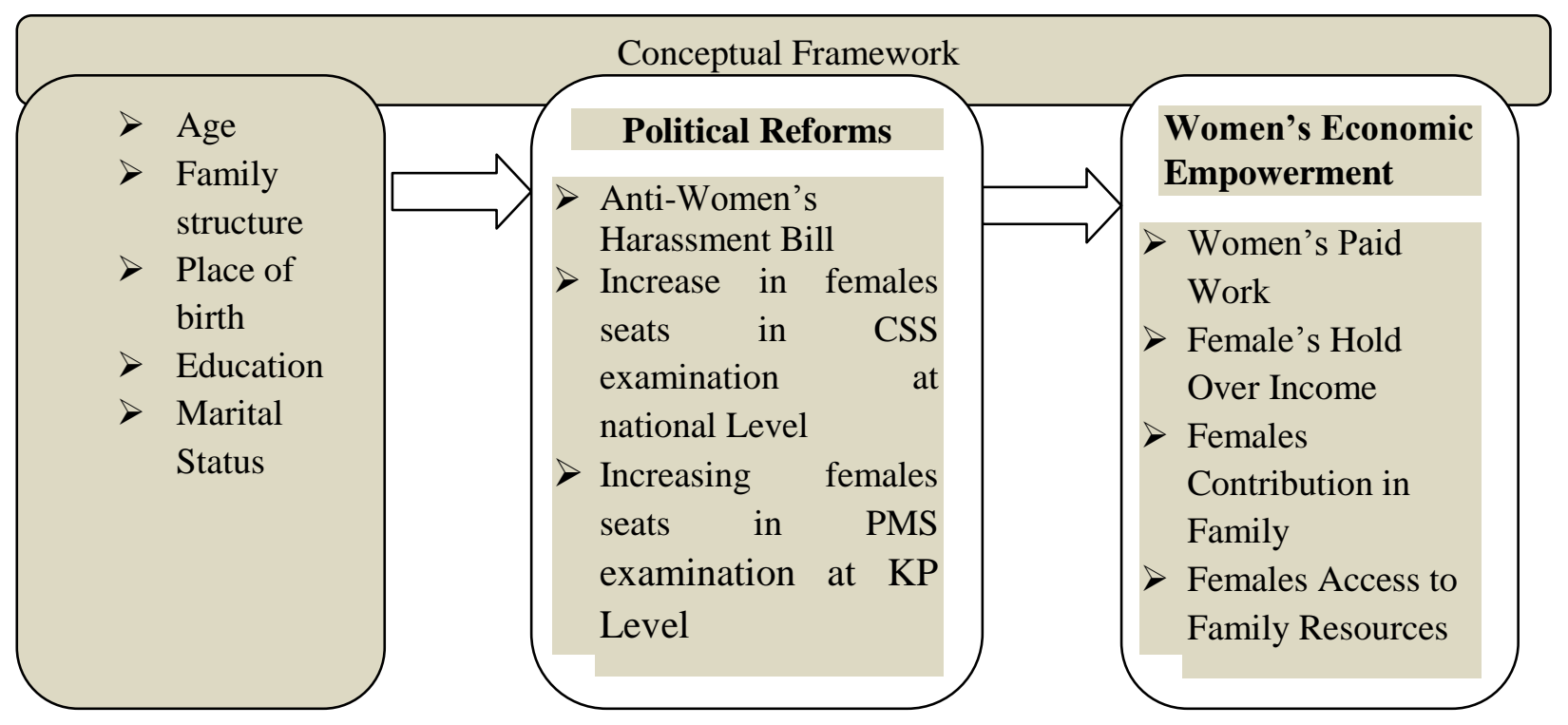

The study analyzed the impact of the political changes on female's economic independence in Khyber Pakhtunkhwa, Pakistan. The researchers believed in the positivist paradigm as a key methodological application in this study which guides quantitative methodology. The selection of the mentioned methodology was made in connection to research questions (women economic empowerment) and researchers' expertise. Additionally, the most important logic for the selection of quantitative methodology was its suitability for quantifying women's economic empowerment quantitatively. After meeting some basic preconditions, the researchers collected data from 400 women political representatives (189 from tehsil Swabi and 211 from tehsil Mardan). By women political representatives, the researchers meant all those women who represent their political community on different political levels. The selection of the women political representatives for data collection was made in line with the research objectives that they could be suitable for providing potential information about their economic empowerment. Besides, the main reason behind selecting the mentioned tehsils for the collection of data was that these both are among the most politically fertile tehsils in the province of KP.

The interview schedule was used as an instrument of data collection. The interview guide was composed of two parts. Part first was comprised of questions regarding women's knowledge which they have about the political changes (i.e. women knowledge about anti-harassment bill and their information about women's seats in PMS and CSS exams) brought on provincial and national levels. However, the second part was included in question about their economic empowerment i.e. women's paid work, their control over income, women's access to family resources. The data collected through interview schedule were first entered into and managed through SPSS and then descriptive and 
inferential statistics were applied for analysis. The socio-demographic variables were analyzed through simple frequency and percentage. However, an independent sample t-test was applied to examine political changes' influence on female's economic independence. It is worthwhile to mention here that through t-test statistics the researchers analyzed the impact of two different groups of independent variables (i.e. females with information about political changes and females without information about the political changes) differently on their economic independence. After managing and analyzing data through the mentioned statistical tests, the following contents were extracted and presented.

Results and Discussion

Descriptive Analysis

Table 01: Socio-demographic Features of the Participants ( $N=400)$

\begin{tabular}{|c|c|c|c|c|c|}
\hline \multicolumn{3}{|c|}{ 1.1 Participants' Tehsil } & \multicolumn{3}{|c|}{ 1.2 Participant's Family type } \\
\hline Categories & Frequency & Percent & Categories & Frequency & Percentage \\
\hline Mardan & 211 & 52.7 & Nuclear Family & 229 & 57 \\
\hline \multirow[t]{2}{*}{ Swabi } & 189 & 47.3 & Joint Family & 163 & 41 \\
\hline & & & \multicolumn{2}{|c|}{ Extended Family8 } & 2 \\
\hline Total & 400 & 100.0 & & 400 & 100.0 \\
\hline \multicolumn{3}{|c|}{ 1.3 Participant's Age (Years) } & \multicolumn{3}{|c|}{ 1.4 Participant's Qualification } \\
\hline Categories & Frequency & Percent & Categories & Frequency & Percentage \\
\hline $16-25$ & 91 & 22.7 & Illiterate & 23 & 6 \\
\hline $26-35$ & 210 & 52.5 & Matric & 75 & 19 \\
\hline $36-45$ & 79 & 19.7 & Intermediate & 76 & 19 \\
\hline $46-55$ & 15 & 3.7 & Bachelor & 147 & 37 \\
\hline Above 55 & 5 & 1.3 & above Master & 79 & 19 \\
\hline Total & 400 & 100.0 & & 400 & 100.0 \\
\hline \multicolumn{6}{|c|}{ 1.5 Participant's Marital Position } \\
\hline$\overline{\text { Categories }}$ & Frequency & Percent & & & \\
\hline Single & 136 & 34 & & & \\
\hline Married & 256 & 64 & & & \\
\hline Divorced/Widowed & 8 & 2 & & & \\
\hline Total & 400 & 100.0 & & & \\
\hline
\end{tabular}

Explanation: In table 1 the respondent's social features are presented. This study selected 400 respondents (i.e. 211 (52.7 percent) from Tehsil Mardan and 189 (47.3 percent) from swabi) of the Mardan Division, KP Pakistan. Similarly, the table reveals respondents' age in which 52.5 belong to 26-35 years of age, 22.7 percent from age cluster 16-25 years, 19.7 percent from age group 36-45 years, and the last five percent portion of the respondents were selected from age cluster of 46 and above 46 years. Participant's minimum age in this study was 16 years while was 70 years. The majority of participants belonged to 26-35 years of age. 64 percent married respondents, 34 percent single, and only $2 \%$ of participants were widowed. The table also reveals the family structure of the respondents in which 57 percent of respondents were from nuclear families, $41 \%$ having combined family and only $2 \%$ were living in extended families. This table indicates a bulk of the participants i.e. $57 \%$ belonged to the nuclear family setup. Moreover, table exhibits participants' education in which $37 \%$ of participants done Bachelors, $19 \%$ were matric, 19\% had done FA/FSC, $19 \%$ were MA/MSC and above qualification and only $6 \%$ participants were illiterate. The table indicates that 37 $\%$ of participants had done a bachelor which comes in the majority.

Table 02: Political Reforms and Women's Economic Empowerment $(\mathrm{N}=400)$

\begin{tabular}{llllll}
\hline \multicolumn{2}{l}{ 2.1 Females are allowed for Outdoor Paid Work } & \multicolumn{3}{l}{ 2.2 Females can Control Income } \\
\hline Categories & Frequency & Percent & Categories & Frequency & Percent \\
Strongly Agree & 72 & 18 & Strongly Agree & 112 & 928 \\
Agree & 269 & 64.8 & Agree & 227 & 56.8 \\
Uncertain & 41 & 10.3 & Uncertain & 43 & 10.8 \\
Disagree & 27 & 6.8 & Disagree & 16 & 4 \\
Strongly Disagree & 1 & .3 & Strongly Disagree 2 & .5 \\
Total & $\mathbf{4 0 0}$ & $\mathbf{1 0 0 . 0}$ & & $\mathbf{4 0 0}$ & $\mathbf{1 0 0 . 0}$ \\
\hline
\end{tabular}




\begin{tabular}{llllll}
\hline 2.3 Women's Economic Support to Family & \multicolumn{2}{c}{ 2.4 Females' Approach to Family Assets } \\
\hline Categories & Frequency & Percent & Categories & Frequency & Percent \\
Strongly Agree & 154 & 38.5 & Strongly Agree & 100 & 25 \\
Agree & 213 & 53.3 & Agree & 223 & 55.8 \\
Uncertain & 19 & 4.8 & Uncertain & 51 & 12.8 \\
Disagree & 14 & 3.5 & Disagree & 25 & 6.3 \\
& & & Strongly Disagree 1 & .3 \\
Total & $\mathbf{4 0 0}$ & $\mathbf{1 0 0 . 0}$ & & $\mathbf{4 0 0}$ & $\mathbf{1 0 0 . 0}$ \\
& & & & &
\end{tabular}

2.5 Females can Own Family Land and Assets

\begin{tabular}{lll}
\hline Categories & Frequency & Percent \\
Strongly Disagree & 71 & 17.8 \\
Agree & 189 & 47.3 \\
Uncertain & 81 & 20.3 \\
Disagree & 47 & 11.8 \\
Strongly Disagree & 12 & 3 \\
Total & $\mathbf{4 0 0}$ & $\mathbf{1 0 0 . 0}$
\end{tabular}

Interpretation: About the statement i.e. females are allowed to join outdoor paid work; the table reveals that $64.8 \%$ participants confirm the statement, $18 \%$ participants have strongly agreed $10 \%$ respondents were uncertain, $6.8 \%$ negate the statement, and only $0.3 \%$ refused that females can join outdoor paid work. The table also explains that participants in the majority (64.8\%) accept females join outdoor paid work. Table further demonstrates participants view regarding the statement that females can hold family income in which explains that $56.8 \%$ of the respondents agreed with the statement, $28 \%$ respondent strongly agreed, $10.8 \%$ remained uncertain, $4 \%$ percent disagreed, and 0.5 percent remains with strong disagreement about the statement that females control the income. Thus the data finds that in the majority $(56.8 \%)$ the respondents remain in agreement with that females control the income. The table further indicates that $53.3 \%$ of participants admit that females have financial contributions to their families, $38.5 \%$ of respondents strongly agreed, $4.8 \%$ remained uncertain, and only $3.5 \%$ of respondents stood strongly disagreed that women are contributing to support their family. Thus information exhibits that the dominant portion of the respondents (53.3\%) accept that females have a contribution to support their family. About the statement "females can hold family resources" information in the table illustrates that $55.8 \%$ participants accept the statement, $25 \%$ participants agreed strongly, $12.8 \%$ participants remained uncertain, $6.3 \%$ participants have disagreed, and a very insignificant number respondents i.e. $0.3 \%$ strongly disagreed with the statement. So the information shows that $55.8 \%$ of respondents make the majority while saying that females can approach the resources of their families. The table also reveals information about "females can own land and assets" in which $47.3 \%$ have the opinion agreed, $20.3 \%$ respondents stood undecided, $17.8 \%$ strongly agreed, $11.8 \%$ respondents disagree, and the last $3 \%$ respondents have strong disagreement that women can have the land and assets. As a result table indicates that the majority of participants $(47.3 \%)$ have agreed upon the statement that women can own the land and assists.

Inferential Analysis

Table 03: T-test statistics between the information regarding Political changes and Economic Independence of Females

\begin{tabular}{llll}
\hline Information about Administrative changes & Mean & St. Dev & Confidence Interval \\
\hline Female's Seats in PMS Examination & & & \\
$\quad$ Yes & 10.32 & 3.018 & $-1.744-0.429$ \\
$\quad$ No & 9.23 & 2.685 & \\
$\quad$ t-value & $-3.247^{* *}$ & & \\
Female's Seats Increase of CSS Examination & & & \\
$\quad$ Yes & 10.28 & 2.765 & $-1.351-0.118$ \\
$\quad$ No & 9.54 & 2.813 & \\
t-value & $-2.341^{*}$ & & \\
& & &
\end{tabular}


Note: (ns) mean not significant

$\mathrm{P}<0.001^{* * *}$

$\mathrm{P}<0.01^{* *}$

$\mathrm{P}<0.05^{*}$

The table shows the results of the t-test between the information of participants regarding the political reforms (i.e. females quota in PMS and CSS examinations) and their economic empowerment. Results show that mean (Mean=10.32, S.D=3.018) was higher of those respondents who knew the incensement of seats for women in the PMS examination. Therefore, a significant mean difference was observed between the two groups of respondents (i.e. women with and without knowledge about females seats the provincial management services examination). Females with the information about the reforms were involved more in strengthening their economic status as compared to those who don't have information regarding raise in female's seats in the provincial management services examination at KP province. Moreover, the table also mentions the mean difference between the two groups (i.e. females with information regarding the increase of women seats in CSS examination and women with no knowledge). Thus the results conclude that mean of the respondents having information regarding the said changes was high (Mean=10.28, S.D=2.765) in comparison to those females who had no information regarding the aforementioned reforms. The information recorded a substantial mean difference between women with knowledge regarding the increase of women seats in CSS examination and women with no knowledge) while being struggling for getting jobs and their economic independence in the society.

\section{Conclusion}

The study analyzed the impact of political changes on female's economic independence in Khyber Pakhtunkhwa, Pakistan. It found that female's information regarding the political changes on the whole was not bad. However, women's economic empowerment was not affected that much positively. Women's paid work found very poor because they were not paid that much sound like men job holders in the market. Women's control over family income also found insufficient in comparison to their men members of the family. The impact of the political changes on female's contribution to their family finances was also not good because they were earning less in jobs as compared to their male cohorts so their contribution to the family was also affected negatively. As the whole system on the public and private domains was men dominated so women's access to family resources was also not encouraging. Based on the mentioned indicators, the study, on the whole, unearthed a very poor impact of the political changes on the economic empowerment of women. However, one positive aspect was noted that with the increase of women's knowledge and awareness about political reforms, their economic independence was also improving. The study suggests that women's education and awareness about their empowerment should be improved and they should be kept updated about each policy of the government produced for their overall empowerment. In the end, it is important to state that the conclusion of this study is drawn through the statistical analysis of the respondent's views which may include some minor deficiency. To cover this inadequacy, future researches may be conducted on the comparative analysis of the political reforms along with other relevant factors and women's actual empowerment so that adequacy in concluding may be ensured.

\section{References}

Abu-Lughod, L. (2009). Dialects of women's empowerment: The international circuitry of the Arab Human Development Report 2005. International Journal of Middle East Studies, 41(1), 83103.

Abdullah, H. J., \& Fofana-Ibrahim, A. (2010). The Meaning and Practice of Women's Empowerment in Post-conflict Sierra Leone. Development, 53(2), 259-266.

BILAL, M., TUFAIL, M., AHMAD, D. S., \& KHAN, B. A. (2016). Political Reforms and Women's Economic Empowerment in Khyber Pakhtunkhwa, Pakistan. Discourse, 2(02).

Duflo, E. (2012). Women empowerment and economic development. Journal of Economic literature, 50(4), 1051-79.

Goetz, A. M., \& Gupta, R. S. (1996). Who takes the credit? Gender, power, and control over loan use in rural credit programs in Bangladesh. World development, 24(1), 45-63. 
Hassan, M. (2009). Women at the Intersection of Turkish Politics, Religion, and Education: The Unexpected Path to Becoming a State-Sponsored Female Preacher. Comparative Islamic Studies, 5(1).

Kabir, S. L. (2013). Key issues in women's representation in bureaucracy: Lessons from South Asia. Public Organization Review, 13(4), 427-442.

Lindsey, L. L. (2015). Gender roles: A sociological perspective. Routledge.

Marilley, S. M. (1996). Woman suffrage and the origins of liberal feminism in the United States, 18201920. Harvard University Press.

Mill, J. S. (1869). The subjection of women (Vol. 1). Transaction Publishers.

Moghadam, V. M. (2010). Gender, Politics, and Women's Empowerment. In Handbook of Politics (pp. 279-303). Springer, New York, NY.

Naz, A., \& Ahmad, W. (2012). Socio-cultural impediments to women political empowerment in Pakhtun society. Academic Research International, 3(1), 163.

Sadruddin, M. M. (2013). Sexual harassment at workplace in Pakistan-Issues and remedies about the global issue at managerial sector. Sadruddin, MM (2013). Sexual Harassment at Workplace in Pakistan-Issues and Remedies about the Global Issue at Managerial Sector, Journal of Managerial Sciences, 7(1), 113-125.

Tabassum, N., Afzal, T., \& Tabassum, H. (2013). Women in Pakistan: Experiences from women's literacy and empowerment initiative in rural Sindh. The Women-Annual Research Journal of Gender Studies, 5.

Ullah, R. (2018). Socio-Cultural and Economic Factors Affecting Women Political Participation in Dir District of Khyber Pakhtunkhwa. The Women-Annual Research Journal of Gender Studies, 10(10).

Verge, T., \& De la Fuente, M. (2014). Playing with different cards: Party politics, gender quotas and women's empowerment. International Political Science Review, 35(1), 67-79.

Yazdani, F. (2003). Women's representation in local government in Pakistan: Impact analysis and future policy implications. Centre for Policies Studies, Central European University.

Zia, A. S. (2018). Faith and feminism in Pakistan. Sussex Academic Press. 